\title{
Agro-economic Feasibility of Intercropped Systems of Radish and Cowpea-Vegetable Manured With Roostertree Biomass
}

\author{
Maria Francisca Soares Pereira ${ }^{1}$, Francisco Bezerra Neto ${ }^{1}$, Aurélio Paes Barros Júnior ${ }^{1}$, \\ Paulo César Ferreira Linhares ${ }^{1}$, Maiele Leandro da Silva ${ }^{2} \&$ Hamurábi Anizio Lins ${ }^{1}$ \\ ${ }^{1}$ Department of Agronomic and Forest Sciences, Federal Rural University of Semi-arid, Mossoró, RN, Brazil \\ ${ }^{2}$ Agronomy Department, State University of Mato Grosso do Sul, Aquidauana, MS, Brazil \\ Correspondence: Aurélio Paes Barros Júnior, Plant Sciences Center, Department of Agronomic and Forest \\ Sciences, Federal Rural University of Semi-arid, Avenida Francisco Mota, 572, Costa e Silva, CEP: 59625-900, \\ Mossoró, RN, Brazil. Tel: 55-(84)-933-178-548. E-mail: aurelio.barros@ufersa.edu.br
}

Received: May 20, 2018

Accepted: July 22, 2018

Online Published: September 15, 2018

doi:10.5539/jas.v10n10p206

URL: https://doi.org/10.5539/jas.v10n10p206

\begin{abstract}
The association of crops presents as one of the cultivation practices to be used in the systems of vegetable crop production in the northeast Brazil semiarid, fertilized with biomass of spontaneous species of the Caatinga biome as green manure. Under this approach, a study was performed during the period from June to December 2013, in the research area of the Experimental Farm belonging to the Universidade Federal Rural do Semi-árido, Mossoró, RN (Brazil), to assess the feasibility of the agro-economic efficiency of the radish $\times$ cowpea-vegetable association manured with different amounts of roostertree biomass in semiarid environment. A randomized complete block design was used with four treatments and five repetitions. The treatments were composed of four biomass amounts of roostertree incorporated to the soil $\left(10,25,40\right.$ and $55 \mathrm{t} \mathrm{ha}^{-1}$ on a dry basis). The highest agronomic and economic efficiencies of the intercropping of radish with cowpea-vegetable were obtained with the incorporation of 53 and $47 \mathrm{tha}^{-1}$ of roostertree biomass added to the soil. The roostertree spontaneous species of the Caatinga biome it is showed as an efficient green manure in the association of radish with cowpea-vegetable.
\end{abstract}

Keywords: agro-economic efficiency, Calotropis procera, intercropping, Raphanus sativus, Vigna unguiculata

\section{Introduction}

The economic efficiency of agricultural production resulting from lower production unit costs (costs per unit of product), is related to the increased soil fertility and the optimization of acreage (Reis, 2002). Accordingly, the intercropping system can promote this optimization of the area through the complementary of the components crops as well as through manuring with native plant species (Batista et al., 2016; Silva et al., 2017).

The intercropping system in northeastern Brazil has recently been recognized as a potentially beneficial system of agricultural production of vegetable crops, because in a time unit increases overall crop yields per unit of land, in exclusive reason of spatial reorganization of plants in the cultivated area, i.e. no additional costs when compared with traditional monoculture system (Ribeiro et al., 2017). This possibility can be easily checked, since the spaces between the vegetable crops can be better utilized by means of cultivation with crops of short cycle such as radish and cowpea-vegetable.

Rezende et al. (2005) reported that intercrops of radish and lettuce were economically advantageous when compared to their monocultures, resulting from the higher increase in the revenue in relation to the increase observed in the cost of production. Catelan et al. (2002a), in an intercropping of lettuce and radish, obtained net income higher than monocultures in $73.13 \%$ considering the lettuce, and in $11.36 \%$ taking into account the radish crop.

On the other hand, it is known that one of the management practices of crop and soil that can further improve the agroeconomic efficiency of the intercropping systems between vegetable crops is the fertilization with spontaneous species of Caatinga. This practice provides significant improvements in chemical, physical and biological characteristics of the soil. 
The chemicals characteristics are benefited by the release of nutrients with the decomposition of waste, while the physicals are favored by soil aggregation, improved water retention, preventing it from erosion. The biomass of green manure improves soil biological characteristics thus becoming food for microorganisms (Nascimento \& Mattos, 2007).

Other advantages of using green manures are: decreasing of the number of fungal pathogens with the waste decomposition (Wiggins \& Kinkel, 2005); control of nematode and of some insects, by the increase of biodiversity (Caamal-Maldonado et al., 2001); lower soil thermal amplitude (Torres, 2003); decreasing of soil acidity, and raising pH (Nascimento et al., 2003). In this way, green manuring is an alternative to reduce the external energy supply to rural property, increasing the sustainability of the system.

Bezerra Neto et al. (2013a) studying the intercropping of beet with cowpea-vegetable manured with different amounts of roostertree, observed that the score of the canonical variable of the intercropping system, which measures the agronomic efficiency increased with increasing roostertree amounts, about 2.00 in its value between the lowest and the highest amount of green manure added to the soil, registering a maximum score of 3.95 obtained in the largest roostertree biomass amount of $55 \mathrm{t} \mathrm{ha}^{-1}$. These same authors, working with the agronomic efficiency of carrot intercropped with cowpea-vegetable under different amounts of roostertree biomass, optimized the canonical variable score in value of 2.46 in the amount of $46.0 \mathrm{t} \mathrm{ha}^{-1}$ of the green manure (Bezerra Neto et al., 2013b).

Thus, this study had the objective of assessing the feasibility of the agronomic and economic efficiency of the radish $\times$ cowpea-vegetable association manured with different roostertree biomass amounts in semiarid environment.

\section{Matherial and Methods}

\subsection{Site Description}

A study was performed from June to September 2013 in Mossoró, RN, Brazil ( $5^{\circ} 113^{\prime} \mathrm{S}$ and $\left.37^{\circ} 20^{\prime} \mathrm{W} \mathrm{Gr}\right)$ in the experimental area of the Universidade Federal Rural do Semi-Árido (UFERSA), where the climate of the region is of the BSh group, tropical and semi-arid (Batista et al., 2013). In the period of the experiment conduction, the average temperature was $27{ }^{\circ} \mathrm{C}$; the minimum average $25^{\circ} \mathrm{C}$; the average maximum $31{ }^{\circ} \mathrm{C}$; rainfall $0 \mathrm{~mm}$; average solar radiation $918 \mathrm{kj} \mathrm{m}^{-2}$; average relative humidity $66 \%$; average atmospheric pressure $1011 \mathrm{hPa}$; average wind speed $4 \mathrm{~m} \mathrm{~s}^{-1}$ and average temperature of the dew point $19^{\circ} \mathrm{C}$.

The research area soil was of the Dystrophic Yellow Red Latosol type (Oliveira et al., 2015), where fifty simple soil samples were taken to a depth of $0-20 \mathrm{~cm}$, and posteriorly homogenized in order to obtain a composite sample, which after analyzed provided the following results: $\mathrm{pH}$ (in water) $=7.09 ; \mathrm{OM}=11.5 \mathrm{mg} \mathrm{dm}^{-3} ; \mathrm{N}=0.04$ $\mathrm{g} \mathrm{kg}^{-1} ; \mathrm{P}=15.14 \mathrm{~g} \mathrm{~kg}^{-1} ; \mathrm{K}=50.5 \mathrm{mg} \mathrm{dm}^{-3} ; \mathrm{Ca}=1.84 \mathrm{cmol}_{\mathrm{c}} \mathrm{dm}^{-3} ; \mathrm{Mg}=1.39 \mathrm{cmol}_{\mathrm{c}} \mathrm{dm}^{-3} ; \mathrm{Na}=4.1 \mathrm{mg} \mathrm{dm}$ and $\mathrm{CEC}=3.38 \mathrm{cmol}_{\mathrm{c}} \mathrm{dm}^{-3}$.

\subsection{Experimental Procedure}

The experimental design used in this research was of randomized complete blocks with four treatments and five repetitions. The treatments were composed of four biomass amounts of roostertree added to the soil $(10,25,40$ and $55 \mathrm{t} \mathrm{ha}^{-1}$ on a dry basis). These amounts were incorporated into the soil in each experimental plot at 20 days before sowing (Linhares et al., 2011). The area of each plot was of $3.60 \mathrm{~m}^{2}(3.00 \mathrm{~m} \times 1.20 \mathrm{~m})$ with $2.00 \mathrm{~m}^{2}$ of harvest area.

\subsection{Management and Cropping System}

The planting area of the research was cleaned with a tractor attached a plow. After this, a harrowing and beds lifting was performed. In all these beds was held a solarization with a plastic type Vulcabrilho Bril Fles of 30 microns during 35 days in order to strike the phytoparasites of the soil in the layer $0-10 \mathrm{~cm}$ to protect the crops (Linhares et al., 2017).

The green manure used in the fertilizing of this research was collected in the micro-region Mossoró-Apodi of the Rio Grande do Norte state, Brazil and ground up in 2-3 cm pieces and dried until to reach the point of hay at room temperature, and then stored with a moisture content around $9 \%$. Subsequently, nutrient content analyzes were performed on samples randomly selected from this fertilizer, providing the following chemical composition: $15.3 \mathrm{~g} \mathrm{~kg}^{-1} \mathrm{~N} ; 4.0 \mathrm{~g} \mathrm{~kg}^{-1} \mathrm{P} ; 15.7 \mathrm{~g} \mathrm{~kg}^{-1} \mathrm{~K} ; 9.3 \mathrm{~g} \mathrm{~kg}^{-1} \mathrm{Ca} ; 7.03 \mathrm{~g} \mathrm{~kg}^{-1} \mathrm{Mg}, 4.39 \mathrm{~g} \mathrm{~kg}^{-1} \mathrm{~S}$, and a ratio of Carbon:Nitrogen of 20:1.

The establishment of the intercropping of radish with cowpea-vegetable was carried out in alternating strips of planting in the proportion of $50 \%$ of area occupied for each crop. Each strip was composed of four rows of each 
culture and flanked by two guard rows of cowpea-vegetable on one side and two guard rows of radish on the other side, called of lateral borders.

The cultivated radish and cowpea-vegetable cultivars in the intercropping systems were respectively the 'Crimson Giant' and the 'BRS Itaim'. The radish crop was planted at the spacing of $0.25 \mathrm{~m}$ between rows, with 10 plants per linear meter, and the cowpea-vegetable with 25 plants per linear meter.

The planting of the cultivars of each culture in single crop was carried out in each block of the experiment in its optimum population recommended by the research in the semi-arid region of northeastern Brazil. The spacing of the radish crop was $0.20 \mathrm{~m} \times 0.10 \mathrm{~m}$ and the cowpea-vegetable was $0.50 \mathrm{~m} \times 0.10 \mathrm{~m}$, thus providing a population density per hectare of 500,000 (Batista et al., 2013) and 200,000 plants, respectively. These same populations were used in each treatment of the radish $\times$ cowpea-vegetable intercropping. The planting of the radish and of the cowpea-vegetable was done on the same day, but specifically on 07/19/2013 and the thinning of these crops was carried out, respectively, at seven and ten days after the emergency.

The experiment was irrigated with micro-sprinklers in two shifts per day, one in the morning and another in the afternoon, with an average flow of water of about $8 \mathrm{~mm}$ a day, thus maintaining the soil of each experimental plot between 50 and $70 \%$ of the capacity of field, thus providing the ideal condition for the nitrification process (Meurer, 2007). Weeds were removed manually twice times.

The radish harvest was carried out 35 days after sowing. In the cowpea-vegetable harvesting, five harvests were performed, finishing the last one at 65 days after sowing.

\subsection{Measured Characteristics}

The characteristic evaluated in the radish crop was the productivity of commercial roots (obtained from the fresh mass weight of plant roots of the harvest area, free of cracks, bifurcations, nematodes and mechanical damage, expressed in $\mathrm{t} \mathrm{ha}^{-1}$ ) and in the culture of the cowpea-vegetable was the yield of green grains (determined of the weight of green grains of the harvest area of each plot, expressed in $t \mathrm{tha}^{-1}$ ).

The agronomic efficiency of the intercrops was obtained by the land equivalent ratio (LER), derived from the sum of the partial land equivalent ratios for radish $\left(\mathrm{LER}_{\mathrm{r}}\right)$ and for cowpea-vegetable $\left(\mathrm{LER}_{\mathrm{cv}}\right)$. These partial LERs were calculated by the following expressions: $\mathrm{LER}_{\mathrm{r}}=\mathrm{I}_{\mathrm{r}} / \mathrm{S}_{\mathrm{r}}$ and $\mathrm{LER}_{\mathrm{cv}}=\mathrm{I}_{\mathrm{cv}} / \mathrm{S}_{\mathrm{cv}}$, where, $\mathrm{I}_{\mathrm{r}}$ represents the productivity of radish commercial roots in intercropping with cowpea-vegetable and $S_{r}$ represents the productivity of radish commercial roots in single crop. On the other hand, $\mathrm{I}_{\mathrm{cv}}$ represents the green grains yield of cowpea-vegetable intercropped with radish and $\mathrm{S}_{\mathrm{cv}}$ represents the cowpea-vegetable green grains yield in single crop. LER is defined as the relative area of land in single crop that it is required for providing the same productivities achieved in intercropping system.

The economic efficiency of the intercrops studied was assessed through the following economic indicators: gross income, total costs, net income, rate of return and profit margin. The gross income was determined by product of the production value per hectare, based on the price paid to farmers in January 2014 in the city of Mossoró, RN (Brazil), which was $\mathrm{R} \$ 5.93 \mathrm{~kg}^{-1}$ for radish roots and $\mathrm{R} \$ 5.00 \mathrm{~kg}^{-1}$ for green grains of cowpea-vegetable, respectively. The exchange rate of the US dollar in this date was $\$ 1=\mathrm{R} \$ 2.42$.

The total costs were determined in each treatment, computing the costs of the inputs and services used in one hectare of radish and cowpea-vegetable in intercropping system in January 2014 in the city of Mossoró, RN (Brazil). The methodology for its obtainment was the one used by Silva et al. (2015).

The net income was obtained by subtracting from the gross income the total costs of production, from inputs and services, and the rate of return for each real invested per treatment was calculated by the ratio between the gross income and production total cost of each treatment. The profit margin was determined by the ratio between net income and gross income, and expressed in percentage.

\subsection{Statistical Analysis}

Regression analyzes were performed on the characteristics evaluated by the software 'Table Curve' (Systat Software Inc., 2011), and a response equation for each variable was adjusted as a function of the roostertree biomass amounts added to the soil.

\section{Results and Discussion}

\subsection{Agronomic/Biological Efficiency Indices}

The partial land equivalent ratio for radish and the land equivalent ratio for the intercrop increased with the amounts of roostertree biomass added to the soil, achieving the maximum values of 1.46 and 2.51 in the amounts 
of biomass of 49.92 and $52.42 \mathrm{t} \mathrm{ha}^{-1}$, respectively, diminishing then up to the last quantity of roostertree biomass incorporated (Figures $1 \mathrm{~A}$ and $1 \mathrm{C}$ ).

Differently from these ratios, it was observed an increase in the partial land equivalent ratio for cowpea-vegetable with increasing amounts of roostertree biomass of approximately 0.48 , meaning $48 \%$ between the smallest $\left(10 \mathrm{t} \mathrm{ha}^{-1}\right)$ and the largest amount $\left(55 \mathrm{tha}^{-1}\right)$ incorporated to the soil, with a maximum ratio of 1.08 reached in the largest roostertree amount of $55 \mathrm{t} \mathrm{ha}^{-1}$ (Figure 1B).
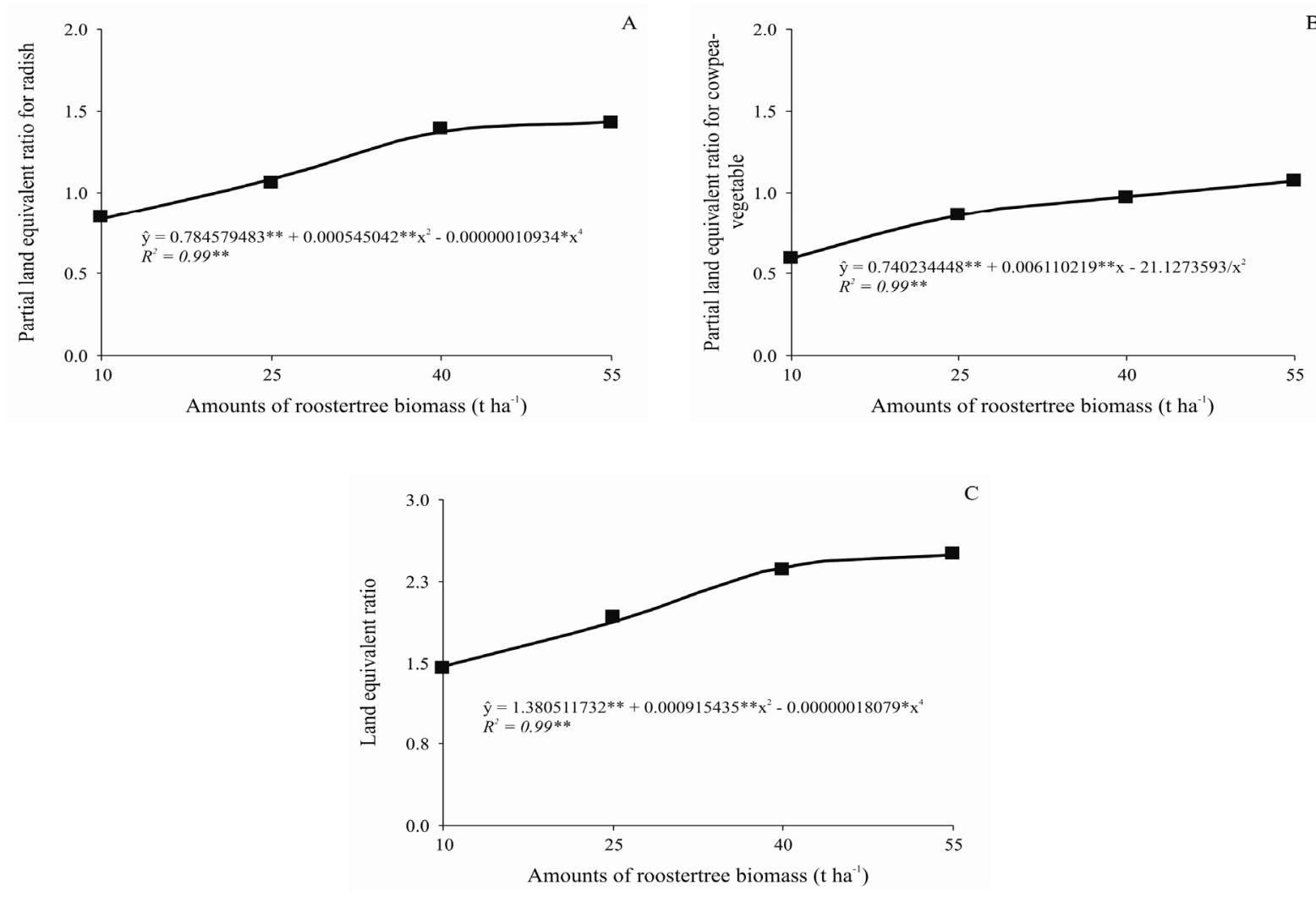

Figure 1. Partial land equivalent ratio for radish (A) and for cowpea-vegetable (B), and land equivalent ratio for the intercropping system $(\mathrm{C})$ under different amounts of roostertree biomass added to the soil

The upward answer of these variables as a function of the increased quantities of roostertree can be attributed to higher nutritional supplying of the radish plants and cowpea-vegetable, and the proper synchronization between the decomposition and mineralization of the roostertree added and time of higher nutritional requirement of culture (Fontanetti et al., 2006; Batista et al., 2013).

According to Vale et al. (2004), the $\mathrm{N}$ mineralization is very influenced by the $\mathrm{C}: \mathrm{N}$ ratio of the decomposing material. So, with the addition of waste of $C: N$ ratio between 20:1 and 30:1, there is neither predominance of immobilization or mineralization of $\mathrm{N}$. The $\mathrm{C}: \mathrm{N}$ ratio of the roostertree was $25: 1$, therefore, within the range explained by the authors above.

All maximum values for partial land equivalent ratios of the component cultures $\left(\mathrm{LER}_{\mathrm{r}}\right.$ and $\left.\mathrm{LER}_{\mathrm{cv}}\right)$ and for the land equivalent ratio of the intercropping system were greater than unity, meaning that there was a better use of environmental resources and of the area by the crops, and of the hand labor in the various operations such as application of inputs and cultural practices with the use of the roostertree in the studied treatments when compared with their respective monocultures, indicating there is a complementarity between crops and an agronomic/biological advantage in the intercropping (Costa et al., 2017; Favacho et al., 2017).

Rezende et al. (2005) working with the radish and lettuce intercropping established in two row spacings and three lettuce transplanting times, observed that the intercropped systems established at zero day (with spacing of 
$0.30 \times 0.30 \mathrm{~m}$ ) and at 14 days after lettuce transplanting (with spacing of $0.40 \times 0.30 \mathrm{~m}$ ) had the highest land equivalent ratios of 1.76 and 1.61 , respectively.

Zucchi et al. (2012) assessing the agronomic efficiency of the cowpea and okra intercropping obtained a land equivalent ratio of 1.44, a result similar to the land equivalent ratio for radish (1.46) and lower than that achieved for radish intercropped with cowpea-vegetable (2.51). This difference is due to the okra in the association.

\subsection{Economic Efficiency Indicators}

Analyzing the economic indicators for gross and net income, rate of return and profit margin, it was registered an increase in their values with increasing amounts of roostertree biomass added to the soil, up to the maximal values of $\mathrm{R} \$ 76.863,06$ and $60.479,91 \mathrm{ha}^{-1}$ (corresponding to $\$ 31,764.59$ and $24,991.70 \mathrm{ha}^{-1}$ ); 3.60 by each real invested and of $72.73 \%$, in the amounts of roostertree biomass of $50.19 ; 51.42 ; 50.52$ and $46.41 \mathrm{t} \mathrm{ha}^{-1}$, respectively, diminishing until the highest roostertree amount added to the ground (Figures 2A, 2B, 2C and 2D).
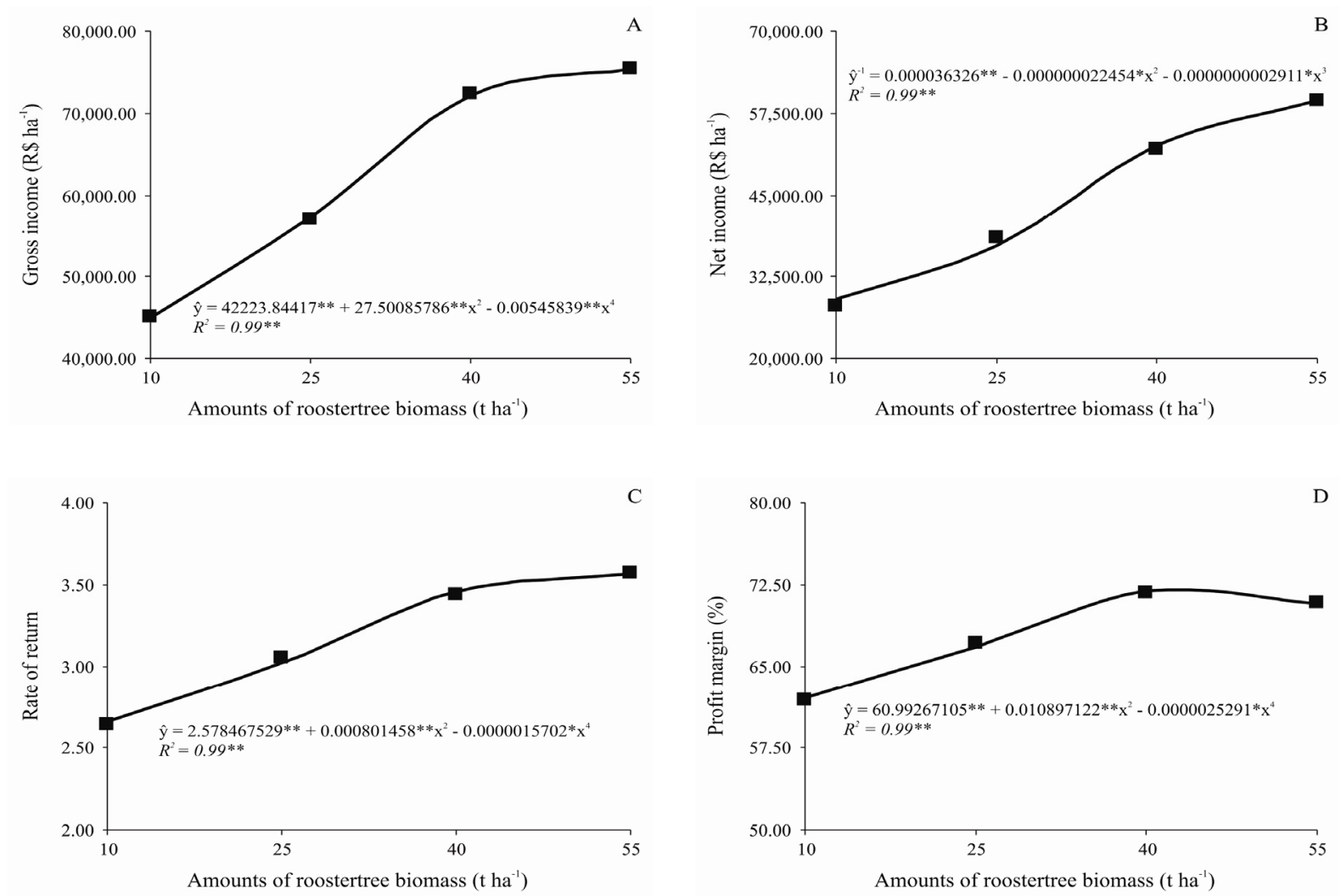

Figure 2. Indicators for gross income (A), net income (B), rate of return (C) and profit margin (D) under different amounts of roostertree biomass incorporated into the soil

It can be inferred from these results that the optimization of the economic performance of the association of radish with cowpea-vegetable was achieved by the incorporating of the biomass quantity of roostertree of $46.41 \mathrm{t}$ $\mathrm{ha}^{-1}$ to the soil, dictated by profit margin, considered a good indicator that best estimates the economic value of the crop association, since in it are deducted production total costs (Bezerra Neto et al., 2012).

These results are due to the fact that both the radish and the cowpea-vegetable (with LER values greater than 1) responded very well to the green manuring, indicating that the estimates of economic indicators came from the best use of the environmental resources by the cultures. Thus, the agronomic performance of the association of radish with cowpea-vegetable has been translated in terms of economic response.

The increasing productivity per unit of area is one of the important reasons for cultivating two or more crops in intercropping system. According to Oliveira et al. (2017), the cultivation of tuberous with leafy vegetables provides better use of the land and other available environmental resources, resulting in higher economic yield. 
Rezende et al. (2005), estimating economic indicators in intercropping systems of radish with lettuce, obtained return rate of 4.13 and 4.53 , and profit margin of 75.77 and $77.94 \%$ respectively, results these close to those obtained in this work. According to the authors, the lettuce and radish intercrops were economically advantageous when compared to their monocultures, due to higher increase in revenue compared to the observed increase in the cost of production.

\section{Conclusions}

(1) The highest agronomic and economic efficiencies of the intercropping of radish with cowpea-vegetable were obtained with the incorporation of 53 and $47 \mathrm{tha}^{-1}$ of roostertree biomass added to the soil.

(2) The roostertree spontaneous species of the Caatinga biome it is showed as an efficient green manure in the association of radish with cowpea-vegetable.

\section{References}

Batista, M. A. V., Bezerra Neto, F., Ambrosio, M. M. Q., Guimarães, L. M. S., Saraiva, J. P. B., \& Silva, M. L. (2013). Soil microbiological attributes and productivity of radish influenced by the use of spontaneous species. Horticultura Brasileira, 31(4), 587-594. https://doi.org/10.1590/S0102-05362013000400013

Batista, T. M. V., Bezerra Neto, F., Silva, I. N., Silva, M. L., Oliveira, E. Q., \& Barros Júnior, A. P. (2016). Agronomic efficiency of the intercropping of arugula with carrot under different population combinations. Revista Caatinga, 29(1), 76-84. https://doi.org/10.1590/1983-21252016v29n109rc

Bezerra Neto, F., Porto, V. C. N., Gomes, E. G., Cecílio Filho, A. B., \& Moreira, J. N. (2012). Assessment of agro-economic indexes in polycultures of lettuce, rocket and carrot through uni-and multivariate approaches in semi-arid Brazil. Ecological Indicators, 14(1), 11-17. https://doi.org/10.1016/j.ecolind.2011.07.006

Bezerra Neto, F., Silva, M. L., Vieira, F. A., \& Silva, R. C. P. (2013b). Performance produtiva de cenoura consorciada com caupi-hortaliça sob diferentes quantidades de flor-de-seda. Congresso Nacional de Feijão-Caupi, 3 (p. 5) [CDROM]. Anais... Recife: Instituto Agronômico de Pernambuco.

Bezerra Neto, F., Silva, M. L., Vieira, F. A., Silva, R. C. P., \& Silva, I. N. (2013a). Consórcio de beterraba com caupi-hortaliça adubado com diferentes quantidades de flor-de-seda. Congresso Nacional de Feijão-Caupi, 3 (p. 5) [CDROM]. Anais... Recife: Instituto Agronômico de Pernambuco.

Caamal-Maldonado, J. A., Jiménez-Osornio, J. J., Torres-Barragán, A., \& Anaya, A. L. (2001). The use of allelopathic legume cover and mulch species for weed control in cropping systems. Agronomy Journal, 93(1), 27-36. https://doi.org/10.2134/agronj2001.93127x

Catelan, F., Canato, G. H. D., Martins, M. I. E. G., \& Cecílio Filho, A. B. (2002). Análise econômica das culturas de alface e rabanete, cultivadas em monocultivo e consórcio. Horticultura Brasileira, 20(2), Suplemento 2 [CDROM]. Trabalho apresentado no $42^{\circ}$ Congresso Brasileiro de Olericultura, 2002.

Costa, A. P., Bezerra Neto, F., Silva, M. L., Lima, J. S. S., Barros Júnior, A. P., \& Porto, V. C. N. (2017). Intercropping of carrot $\mathrm{x}$ cowpea-vegetables: Evaluation of cultivar combinations fertilized with roostertree. Rev Caatinga, 30(3), 633-641. https://doi.org/10.1590/1983-21252017v30n311rc

Favacho, F. S., Lima, J. S. S., Bezerra Neto, F., Silva, J. N., \& Barros Júnior, A. P. (2017). Productive and economic efficiency of carrot intercropped with cowpea-vegetable resulting from green manure and different spatial arrangements. Rev Ciência Agronômica, 48(2), 337-346. https://doi.org/10.5935/1806-6690. 20170039

Fontanetti, A., Carvalho, G. D., Gomes, L. A. A., Almeida, K. D., Moraes, S. D., \& Teixeira, C. M. (2006). Green manure in organic production of American lettuce and cabbage. Horticultura Brasileira, 24(2), 146-150. https://doi.org/10.1590/S0102-05362006000200004

Freire Filho, F. R., Ribeiro, V. Q., Rocha, M. D. M., Silva, K. J. D., Nogueira, M. S. R., \& Rodrigues, E. V. (2011). Cowpea in Brazil: Production, genetic improvement, advances and challenges (1st ed.). Teresina, PI: Embrapa Meio-Norte.

Linhares, P. C. A., Lima, J. S. S., Bezerra Neto, F., Rodrigues, G. S. O., \& Chaves, A. P. (2017). Polycultures of coriander, carrot, and arugula in strip-intercropping system. Rev Caatinga, 30(3), 622-632. https://doi.org/ 10.1590/1983-21252017v30n310rc

Linhares, P. C. F., Silva, M. L., Pereira, M. F. S., Bezerra, A. K. H., \& Paiva, A. C. C. (2011). Quantities and times of decomposition of the silk flower in the agronomic performance of the radish. Rev Verde, 6(1), $168-173$. 
Meurer, E. J. (2007). Factors influencing plant growth and development. In R. F. Novaes (Ed.), Soil fertility (pp. 65-69). Viçosa, MG, Brazil: SBCS.

Nascimento, A. F., \& Mattos, J. L. S. (2007). Benefits with the use of green manures. Revista Brasileira de Agroecologia, 2(3), 41-45. Retrieved from http://revistas.aba-agroecologia.org.br/index.php/rbagroecologia/ article/view/6269

Nascimento, J. T., Silva, I. F., Santiago, R. D., \& Silva Neto, L. F. (2003). Efeito de leguminosas nas características químicas e matéria orgânica de um solo degradado. Revista Brasileira de Engenharia Agrícola Ambiental, 7(3), 457-462. https://doi.org/10.1590/S1415-43662003000300008

Oliveira, L. A. de A., Bezerra Neto, F., Silva, M. L. da, Oliveira, O. F. N., Lima, J. S. S. de, \& Barros Júnior, A. P. (2015). Viabilidade agronômica de policultivos de rúcula/cenoura/alface sob quantidades de flor-de-seda e densidades populacionais. Revista Caatinga, 28, 116-126. https://doi.org/10.1590/1983-21252015v28 n413rc

Oliveira, L. J., Bezerra Neto, F., Lima, J. S. S., Oliveira, E. Q., Moreira, J. N., \& Silva, I. N. (2017). Viability of polycultures of arugula-carrot-coriander fertilized with hairy woodrose under different population densities. Rev Brasileira de Engenharia Agrícola e Ambiental, 21(9), 611-617. https://doi.org/10.1590/1807-1929/ agriambi.v21n9p611-617

Reis, R. P. (2002). Fundamentals of applied economics (28th ed.). Lavras, MG: UFLA/FAEPE.

Rezende, B. L. A., Cecílio Filho, A. B., Catelan, F., \& Martins, M. I. E. G. (2005). Economic analysis of intercropped crops of American lettuce $\times$ radish: A case study. Horticultura Brasileira, 23(3), 853-858. https://doi.org/10.1590/S0102-05362005000300033

Ribeiro, G. M., Bezerra Neto, F., Lima, J. S. S., Silva, M. L., Barros Júnior, A. P., \& Santos, E. C. (2017). Agro-economic efficiency of the intercropping of carrot $\times$ cowpea-vegetable under different spatial arrangements and population densities. Rev Caatinga, 30(4), 847-854. https://doi.org/10.1590/1983-21 $252017 \mathrm{v} 30 \mathrm{n} 404 \mathrm{rc}$

Silva, A. F. A., Souza, E. G. F., Santos, M. G., Barros Júnior, A. P., Bezerra Neto, F., \& Silveira, L. M. (2015). Profitability of the radish fertilized with silk flower in two growing seasons in the semi-arid Pernambuco. Rev de Ciências Agrárias/Amazonian Journal of Agricultural and Environmental Sciences, 58(2), 198-207. Retrieved from http://periodicos.ufra.edu.br/index.php/ajaes/article/view/1761

Silva, J. N., Bezerra Neto, F., Lima, J. S. S., Rodrigues, G. S. O., Barros Júnior, A. P., \& Chaves, A. P. (2017). Combinations of coriander and salad rocket cultivars rin bicropping systems intercropped with carrot cultivars. Rev Caatinga, 30(1), 125-135. https://doi.org/10.1590/1983-21252017v30n114rc

Systat Software. (2011). SigmaPlot for Windows Version 12.0. San Jose: Systat Software Inc.

Torres, J. L. R. (2003). Estudo de plantas de cobertura na rotação milho-soja em sistema de plantio direto no cerrado, na região de Uberaba-MG (p. 21, Tese de Doutorado em Agronomia, Universidade Estadual Paulista, São Paulo, Brazil).

Vale, F. R., Guilherme, L. R. G., \& Guedes, G. A. A. (2004). Fertility of soil: Dynamics and availability of plant nutrients. Lavras, MG, Brazil: Editora UFLA.

Wiggins, B. E., \& Kinkel, L. L. (2005). Green manures and crop sequences influence alfalfa root rot and pathogen inhibitory activity among soil-borne streptomycetes. Plant and Soil, 268(1), 271-283. https://doi.org/10.1007/s11104-004-0300-x

Zucchi, M. R., Perinnazzo, F. K., Peixoto, N., Mendanha, W. R., \& Zatarin, M. A. (2012). Association of crops of okra and cowpea. Rev Agrotecnologia, 3(2), 12-23. https://doi.org/10.12971/agrotec.v3i2.403

\section{Copyrights}

Copyright for this article is retained by the author (s), with first publication rights granted to the journal.

This is an open-access article distributed under the terms and conditions of the Creative Commons Attribution license (http://creativecommons.org/licenses/by/4.0/). 